\section{B A Institute of \\ YK Business Administration \\ 六下 \\ Karachi \\ Leadership and Ideas for Tomorrow}

Business Review

Volume 15 Issue 2 July-December 2020

$1-15-2021$

\title{
Quality minus junk factor: A study on asset pricing dynamics in the equity market of Pakistan
}

\author{
ShahrBano . \\ International Islamic University, Pakistan \\ Sumayya Chughtai \\ International Islamic University, Pakistan \\ Tahira Awan \\ International Islamic University, Pakistan
}

Follow this and additional works at: https://ir.iba.edu.pk/businessreview

Part of the Finance Commons

\section{(c) (i)}

This work is licensed under a Creative Commons Attribution 4.0 International License.

\section{Recommended Citation}

., S., Chughtai, S., \& Awan, T. (2021). Quality minus junk factor: A study on asset pricing dynamics in the equity market of Pakistan. Business Review, 15(2), 27-50. Retrieved from https://doi.org/10.54784/ 1990-6587.1059 


\title{
Quality minus junk factor: A study on asset pricing dynamics in the equity market of Pakistan
}

\author{
ShahrBano · Sumayya Chughtai · \\ Tahira Awan
}

\begin{abstract}
This study examines the role of quality minus junk factor in explaining cross-sectional differences in stock returns for the equity market of Pakistan. A new factor quality minus junk has been added to the existing Fama \& French three factor model (1993) as a fourth factor to check whether it is priced as a risk factor. The study also compares the explanatory power of the newly proposed model with the existing single-factor Capital Asset Pricing Model (CAPM) and Fama \& French three factor model (1993). A high quality data set of 70 nonfinancial firms listed on the PSX is employed as a sample for the period 20082016. Results show that quality minus junk factor is priced in the equity market of Pakistan and this newly proposed four factor model has significantly higher explanatory power than the existing three factor model.
\end{abstract}

Keywords Asset pricing - Quality minus junk factor - Capital asset pricing model · Fama \& French three factor model

\section{Introduction}

Recent studies in the field of asset pricing document that the financial quality of stocks is a strong predictor of their expected returns (Asness et al 2018; Zaremba 2015). These quality characteristics may vary from country to country and these country-specific factors can be utilized in multifactor asset pricing models to evaluate the performance of different investment strategies (Zaremba 2015). This specific study evaluates the quality characteristics identified and

ShahrBano

International Islamic University-Pakistan

Sumayya Chughtai

International Islamic University-Pakistan

E-mail: sumayya.chughtai@iiu.edu.pk

Tahira Awan

International Islamic University-Pakistan

(C)ShahrBano, Chugtai. S. and Awan. T 2020 
tested by Asness et al (2018), for the very first time in 2014, on Pakistan financial market which is considered to be a rapidly emerging market of Asia.

Although, asset pricing literature focuses on the determinants of risk that impact stock returns however in actuality, economic consequences of market efficiency ultimately rely on prices not returns. Thus, firms with highest quality characteristics set high prices of their stock so that they can finance their operations effectively (Asness et al 2018). Therefore it is important to define the term quality and its characteristics. According to Asness et al (2018) "quality is a characteristic that investors should be willing to pay a higher price for". Because stock return and its price are linked to each other therefore QMJ (quality minus junk) portfolio that invests long quality stocks and shorts junk stocks yields high risk adjusted returns i.e. higher the price of quality of stock, lower will be its return.

By making Gordon Growth Model (1956) a foundation, quality characteristic is decomposed into four components; profitability, growth, safety and payout. High profitability, growth and safe stocks command a higher price. However, in case of payout, more the payout of a company, lower will be its future profitability and growth resulting in lower price of stock. But as payout is a portion of profits delivered to shareholders, so higher dividends also help in reducing agency problems. Therefore, if all other factors are held constant, high payout may also yield higher price. All these four components are scored for all stocks of firms listed in any stock exchange and their collective score then reflects quality of that firm. The portfolios are then designed by sorting out low quality stocks from high quality stocks. This QMJ (quality minus junk) factor then helps in predicting the returns of the stocks by being an important risk factor of the multiple factor asset pricing model.

\section{Literature Review}

Numerous researches have been conducted to analyze the behavior of risky assets based on their prices. In literature many theories have also been presented in this regard. Here, a few theories regarding asset pricing are discussed that will help in determining the role and impact of variables under consideration.

Traditional finance theory posits that financial markets are efficient, all publicly available information is incorporated in the price of the stocks and investors make rational investment decisions. This idea was developed by Eugene Fama in 1960. Efficient market has three forms; weak form of market efficiency, semi strong form of market efficiency and strong form of market efficiency. Weak form states that information in the market is available due to historical prices and no one can beat the market based on such information. In semi strong form all new and old information is reflected in the prices of stocks so no investor can get abnormal returns on the basis of this newly available information, because stocks absorb this new information readily after it is released, but only through insider trading. In strong form of market efficiency both public and private information is incorporated in the stock prices and no one can beat the market even by insider trading. The efficient market hypothesis however has been tested 
by many researchers and evidence indicates that it fails to explain the trading norms in real capital markets. Therefore better frameworks are needed to explain the concept of capital markets and their performance in the real world.

Capital asset pricing model is an extension of Markowitz's work presented by Sharpe in 1964. Capital asset pricing model (CAPM hereafter) describes systematic risk return relationship under the condition of general market equilibrium and assumption of linear movements of security returns with the market index movements. According to this theory, investors should be compensated for time value of money as well as risk.

If risk and return are plotted on a graph, risk free rate is determined at the point where a line tangent to the efficient portfolio cuts the vertical axis. Beta is actually the sensitivity of a particular security with respect to the fluctuations in the market and shows the correlation of volatility of stock and market. In CAPM model risk and return increase in a linear manner along the straight-line from the risk free rate to the market portfolio, and this leads to the creation of the security market line. Security market line (SML) equation along with the return on risk free asset and on market portfolio, helps in estimating the required rate of return of any asset depending upon its systematic risk. Despite the important contribution of CAPM in asset pricing models, it is still highly criticized by academicians and practitioners. The reason behind this criticism is the market beta which was the only risk factor that was included to explain the cross-sectional differences in returns.

Fama and French (1993) identified two significant factors other than market risk for explaining cross-sectional returns. These factors are size of the firm and book to market value of stocks. This three-factor model has been tested by Fama and French (1998) and in other studies as well. This model explains average returns more accurately than CAPM. Carhart (1997) extended the three-factor model of Fama and French by identifying a fourth factor, momentum. Momentum in an asset is defined as tendency for the stock price to keep increasing if it is going up and keep decreasing if it is going down.

A five-factor model has also been presented by Fama and French in which they include two more factors; operating profitability and investment patterns of firms in their three factor model. Five factor model has better explanatory power than the three factor model i.e. it explains $71 \%$ - $94 \%$ of variance in stock returns yet it still fails to capture low average returns of small stocks.

Asness et al (2018) came up with an other risk factor which they named as quality minus junk. According to them, quality of stocks also affects their returns. Whether investment made on the basis of quality of stock is worth considering, it is important to first understand what quality actually means. Asness et al (2018) provided a broad definition of quality by decomposing Gordon's growth model into four components namely; profitability, growth, payout and safety. Gordon's growth model (1956) is used to determine the intrinsic value of a stock on the basis of its future dividends that grow at a constant rate. It is written as:

$$
V=\frac{\text { Dividendinnextperiod }}{\text { Requiredrate }- \text { Growthrate }}
$$

Business Review: (2020) 15(2):27-50 
Rewriting this model gives,

$$
\frac{P}{B}=\frac{\frac{\text { Profit }}{B} \times \frac{\text { Dividend }}{\text { profit }}}{\text { Requiredreturn }- \text { Growth }}
$$

or

$$
\frac{P}{B}=\frac{\text { Profitability } \times \text { PayoutRatio }}{\text { Requiredreturn }- \text { Growth }}
$$

Here prices are scaled by book values to make them more stationary over time and in the cross section. The other four variables are considered as the components of the quality measure.

Many studies have discussed these quality components separately in detail and their relationship with stock returns and their price fluctuations. For example Frankel and Lee (1998) conducted a study to examine the predictive power of accounting based ratios for cross sectional variation in stock returns and found that more than $70 \%$ of this variation can be explained by using fundamental values from accounting data of a firm. Ang et al (2006) showed that there exists a negative relationship between stock returns and one month lagged idiosyncratic volatility. In 2008, AHXZ pointed towards the fact that stocks with not easily diversifiable factors do not follow this pattern. Capital asset pricing model (Sharpe, 1964) suggested that only systematic risk is priced and not the idiosyncratic risk but $\mathrm{Fu}(2009)$ argued that it is not necessary that all investors hold perfectly diversified portfolios and so in such a case idiosyncratic risk should be priced. By making this argument the basis of the study, a significant positive relation between idiosyncratic risk and stock returns was documented.

Relating to the issues of dividends payment, dividend puzzle by Black (1976) and Modigliani and Miller (1961) dividend irrelevance theory drew attention of researchers towards this important phenomenon. Further studies reveal the fact that investors do pay attention towards dividend payment due to tax issues and different liquidity needs (John \& William 1985, Allen 2000). Though Miller and Modigliani (1961) assumed that investors and management have equal and perfect knowledge about a company but in reality this is not the case. There exists information asymmetry in the market i.e. management of a firm that manages its operations on a daily basis has more and updated knowledge about the overall condition of a company than the outside investors. Thus to bridge this gap of information between management and investors, dividends are used as a tool to send a positive signal or indirectly some private information in the market about the bright future prospects of a company and therefore this dividend payment affects the stock price movement. That's why Hussainey et al (2011) observed a positive relation between dividend yield and stock price and negative relation between dividend payout ratio and stock price changes in his study.

As shares issuance or repurchase affects dividend yield, it also affects stock returns. The reason behind shares issuance or their repurchase may be market timing because in an inefficient market, mispricing advantage can be taken by mispricing while in an efficient market, market timing may be considered as capital adjustment made in reaction to changes in a firm's exposure to a certain systematic risk. Thus whether a market is efficient or not, share issuance 
helps in forecasting stock returns. Stock issuance or its repurchase may have certain motives behind it for example company wants to meet its cash flow needs, attain certain tax advantages or fulfill regulatory requirements. If share issuance would not have any effect on future stock returns then countries with high issuance cost will have low share issuance activity. But it is observed that positive returns are followed by share purchases while low returns in case of share creation (Mclean, Pontiff, Watanabe, 2009). Similar results were obtained while studying seasoned equity offerings effect on stock returns which turned out to be negative (Pontiff and Woodgate 2008).

Unlike Asness et al (2018), Novy-Marx (2013) showed that profitable companies generate significantly higher average returns than un-profitable companies, although they have low book-to-market ratio and high market capitalization. They argued that if profitability is captured by using gross profits-to-assets ratio, it predicts cross-sectional average returns in the same way as book-to-market ratio. Fama and French (1993) clearly demonstrate that low B/M firms have persistently high earnings and low earnings are observed in high B/M firms. Size effect has also been studied in various studies for example Banz (1981) argued that smaller firms have higher risk adjusted returns than large firms but this effect is prominent in very small firms. However, returns of average size firms and that of large firms do not have very large differences. Therefore, it cannot be said clearly whether size of a firm itself is actually a risk factor or it is just a proxy for some other anomalous factors which are correlated with size.

Dichev (1998) stated that although bankruptcy risk is considered as a proxy for firm's distress and few researchers also consider bankruptcy risk a factor behind size and book-to-market effects, but bankruptcy risk is not compensated through higher returns. Hence he showed that there are no reasons to believe that risk of bankruptcy is a main driving factor behind size and value effects. In 2015, Fama and French extended their three factor model to five factor including operating profitability of firms as a risk factor that should be priced. Another risk factor included in the five factor model was investment patterns which like profitability, is positively correlated to returns. Stocks with high B/M ratio have low profitability and investment and vice versa (Fama and French 2015).

As far as safety of firms and their respective stock is concerned, a more liquid stock is considered safer than the stock with less liquidity therefore expected liquidity of a stock as well as its co-variance with overall market liquidity also affects its required return (Acharya and Pedersen 2005). In another study it was found out that return premium is high among low leverage firms in the time of distress (George and Hwang 2010). Low returns than average returns were observed in case of firms with high risk of bankruptcy (Dichev 1998).

As the direction given by Asness et al (2018) is the basis of this study, all the variables discussed above and their expected results on security prices and returns are considered the same way as described by Asness et al (2018). In their study they created a composite index of quality by combining these four components; profitability, growth, payout and safety. According to their findings, profitable, growing, safe and high payout companies are considered as quality firms. Market can determine stock price on the basis of these quality 
characteristics in advance, if these characteristics are persistent for five or ten years and this persistence of quality pattern can actually be observed in quality firms. Since price and returns are linked to each other, so the price of stocks determined on the basis of their quality will predict the future returns to QMJ (quality minus junk) factor.

This specific study has been conducted to explore the effects of quality minus junk factor on stock returns in the equity market of Pakistan, where it has not been studied before. The reason behind choosing Pakistan equity market lies in the fact that Pakistan is not only an emerging equity market of South Asia but also because of its prime location and rapid economic growth, investors see it as a good investment opportunity. The overall quality of firms operating here matters a lot to the outside world. Therefore it would be worthwhile to know how investors here estimate their required rate of return by making quality as an important determinant and make and amend their portfolio when they foresee changes in fundamentals of firms.

This study also aims to explore the differential aspects of QMJ, if any, resulting due to different environmental setting because asset pricing risk factors may have country specific properties (Griffin 2002).

\section{Data}

This study is quantitative in nature and uses both market and accounting data. In this study annual data of 70 non-financial companies is used which are listed on the Pakistan Stock Exchange (PSX) for the period of 2008-2016 and their financial data is available publicly throughout the period of this study.

The market data includes risk-free rate, stock returns, market returns, market capitalization of stocks and the stock turnover. The share price is determined as closing price on the last trading day of month $t$. T-bill rates are used as a proxy of risk-free rate and the value-weighted index of Pakistan stock exchange i.e. PSX-100 index is used as a proxy of market portfolio. Accounting data refers to the data published in annual reports of the companies for example operating profit of companies, total assets, book value of equity etc. The data is collected from annual reports of the sample companies and websites of Pakistan Stock Exchange and Business recorder which are considered as reliable sources of data.

\section{Methodology}

Same methodology is used to sort stocks and for portfolio designing as used by Fama and French (1993) and Asness et al (2018). Fama and French (1993) use market, size and value factors in the three factor model as explanatory variables to explain portfolio. Later in 2015 they presented their five factor model including operating profitability and investment patterns in their previous three factor model. This five factor model explains $71 \%$ - $94 \%$ of variance in stock returns. So the current study uses these additional factors of Fama and French but through different measures in a different way with the expectation of improved explanatory power of the proposed model. 
4.1 Variables under consideration

The variables used in the study are measured using proxies discussed below. Here independent variable is stock returns however among dependent variables, the market factor is excess return on the market. Theoretically speaking market portfolio includes all available assets and liabilities in a market. The current study uses PSX-100 index as a proxy of the market portfolio. The PSX-100 index is constituted on the basis of top market capitalization firms. The closing prices of PSX-100 index will be used to calculate the market returns.

$$
\text { Marketreturn }=\log \left(\text { closingpriceof stock }_{t} \div \text { closingpriceof stock }_{t-1}\right)
$$

Second dependent variable is the size of firms. Market capitalization will be used as a proxy to measure the size of the firm. Following relationship is used to assess market value or size of the stock $i$ on trading day $t$ (Fama and French 1993).

$$
\text { MarketValue }=\text { Numberofoutstandingshares } \times \text { Marketpricepershare }
$$

Third variable the Book-to-market ratio of each stock is calculated as the total book-value of equity divided by market capitalization or market value of the stock $i$ on trading day $t$. The book value of equity is taken from accounting data and market capitalization of the firm is taken as market value of equity (Fama and French 1993).

$$
\text { Booktomarketratio }=(\text { Bookvalueofequity }) \div(\text { marketvalueofequity })
$$

The proposed fourth risk factor QMJ factor return is calculated by taking average return of two high quality portfolios minus average return on two low quality portfolios which are named as junk portfolios.

$$
Q M J=1 / 2(\text { smallquality }+ \text { bigquality })-1 / 2(\text { smalljunk }+ \text { bigjunk })
$$

or

$$
Q M J=1 / 2(\text { smallquality }- \text { smalljunk })+1 / 2(\text { bigquality }- \text { bigjunk })
$$

\subsection{Quality measures}

Quality factor is decomposed in four other components. These components include profitability, growth, safety and payout. All these components have been estimated through multiple measures to get more robust results. To combine all these measures for obtaining a definite score, they have been standardized by obtaining z-scores.

Profitability is calculated by averaging z-scores of various proxies of profitability including gross profits over assets (GPOA), return on equity (ROE), return on assets (ROA), cash flow over assets (CFOA), gross margin (GMAR),

Business Review: (2020) 15(2):27-50 
and the fraction of earnings composed of cash (i.e. low accruals, ACC). Therefore profitability is the average of z-scores of all its measures.

$$
\text { Profitability }=z\left(z_{\text {gpoa }}+z_{\text {roe }}+z_{\text {roa }}+z_{c f o a}+z_{\text {gmar }}+z_{a c c}\right)
$$

Growth is estimated as change in all profitability measures, under consideration, over a period of one year i.e. growth in gross profits over assets (GPOA), growth in return on equity (ROE), growth in return on assets (ROA), growth in cash flow over assets (CFOA), growth in gross margin (GMAR), and growth in the fraction of earnings composed of cash (i.e. low accruals, ACC). Thus, growth's score is obtained by averaging all of its measures' z scores.

$$
\text { Growth }=z\left(z_{\text {gpoa }}+z_{\text {roe }}+z_{\text {roa }}+z_{c f o a}+z_{\text {gmar }}+z_{a c c}\right)
$$

Safety of stocks can be evaluated by using four different measures which are low beta, low idiosyncratic volatility, low leverage, bankruptcy risk and low earnings volatility. By averaging z-scores of all these measures, safety score is calculated.

$$
\text { Safety }=z\left(z_{b a b}+z_{i v o l}+z_{l e v}+z_{z}+z_{\text {evol }}\right)
$$

Payout component is evaluated by using three different measures which are net equity issuance, net debt issuance and net payout over profits. Thus, payout is the average of all these measures' z-scores.

$$
\text { Payout }=z\left(z_{\text {eiss }}+z_{\text {diss }}+z_{\text {npop }}\right)
$$

Therefore, quality can be determined by its quality score which is calculated on the basis of the z-score of all quality measures i.e. profitability, growth, safety and payout.

$$
\text { Quality }=z(\text { Profitability }+ \text { Growth }+ \text { Safety }+ \text { Payout })
$$

\subsection{Econometric model}

In the light of previous research conducted and gap identification in the literature, following model has been formulated which has one additional factor than the Fama and French three-factor model (1992).

$$
R_{t}=R F R+\beta_{1} M K T_{t}+\beta_{2} S M B_{t}+\beta_{3} H M L+\beta_{4} Q M J_{t}+\varepsilon_{t}
$$

where, $R_{t}=$ expected return of portfolio at time $t, R F R=$ Risk free rate of return on investment at time $t, R_{m}=$ market return at time $t, S M B=$ size premium; small size portfolio return minus big size portfolio return at time $t$, $H M L=$ value premium; High $\mathrm{BV} / \mathrm{MV}$ ratio portfolio return minus low $\mathrm{BV} / \mathrm{MV}$ ratio return at time $t, Q M J=$ Quality minus junk; high quality portfolio return minus low quality portfolio return at time $t$.

\subsection{Estimation method}

The estimation process of the proposed research model has the following steps: 


\subsubsection{Principal component analysis}

For the purpose of constructing a composite index of quality, its proposed components (Asness et al 2018) are tested first through principal component analysis (PCA hereafter). The results of PCA are discussed in this section.

Every individual component of quality has been captured through multiple measures to get robust results. Therefore, first of all, principal component analysis for individual components is performed to check whether the measures used to capture a particular phenomenon truly belong to that component or not. The four proposed and tested components of quality are profitability, growth, safety and payout (Asness et al 2018). The results of PCA confirmed that all measures used for all components rightly capture the related phenomenon and their respective weights are mentioned in the tables 1,2,3, 4. However in case of safety component, low earnings volatility is not used in our study because of non-availability of the required data during the period of study.

After performing principal components analysis of the individual compo-

Table 1: Component matrix of profitability

\begin{tabular}{lccc}
\hline & \multicolumn{3}{c}{ Component } \\
\hline & 1 & 2 & 3 \\
GPOA & & 0.939 & \\
ROE & 0.46 & & \\
ROA & 0.978 & & \\
CFOA & 0.978 & & 1 \\
GM & & & 1 \\
LOW ACCRUALS & & 0.939 & \\
\hline
\end{tabular}

Note: Here GPOA is gross profit over assets, $\mathrm{ROE}$ is return on equity, ROA is return on assets, CFOA is cash flow over assets and GM is Gross margin.

nents of quality measures, these components are then tested again through PCA collectively to make sure whether they capture truly the quality of stocks for the period of study. Results show that safety measure cannot be used to estimate quality of the sample stocks and hence is found redundant. Results are presented in table 5 .

\subsection{Portfolio formation}

To analyze cross-sectional returns on the basis of fundamental values of firms, portfolios are formed instead of studying individual stocks. The reason behind using portfolios is that grouping stocks into portfolios reduces noise in individual stocks as well as errors in variables. In portfolios, the errors in stock returns may cancel each other making the aggregate error effect almost negligible (Fama \& Macbeth, 1973). Here the portfolios are formed on the basis of their quality ranking i.e. high quality stocks are grouped separately from the junk stocks.

Initially size sorted portfolios are formed by arranging them in ascending

Business Review: (2020) 15(2):27-50 
Table 2: Component matrix of growth

\begin{tabular}{lcc}
\hline & \multicolumn{2}{c}{ Component } \\
\hline & 1 & 2 \\
\hline GGPOA & 0.858 & \\
GROE & 0.496 & -0.461 \\
GROA & 0.853 & \\
GCFOA & 0.898 & \\
GGM & 0.859 & \\
GLOWACC & & 0.666 \\
\hline
\end{tabular}

Note: Here GGPOA is growth in gross profit over assets, GROE is growth in return on equity, GROA is growth in return on assets, GCFOA is growth in cash flow over assets, GGM is growth in gross margin and GLOWACC is growth in low accruals.

Table 3: Component matrix of safety

\begin{tabular}{lccc}
\hline & \multicolumn{3}{c}{ Component } \\
\hline & 1 & 2 & 3 \\
LOWBETA & 0.718 & & \\
LOWIDIO & & 0.865 & \\
LOWLEV & & & 0.99 \\
BANKRUPTCYRISK & -0.727 & & \\
\hline
\end{tabular}

Note: Here LOWIDIO is low idiosyncratic volatility and LOWLEV is low leverage.

Table 4: Component matrix of payout

\begin{tabular}{lcc}
\hline \multicolumn{3}{c}{ Component } \\
\hline & 1 & 2 \\
\hline NEISS & 0.764 & \\
NDISS & 0.761 & \\
NPAY & & 0.965 \\
\hline
\end{tabular}

Note: Here NEISS is net equity issuance, NDISS is net debt issuance and NPAY is net payout

order on the basis of their market capitalization. Now median is calculated and sample is divided in two portfolios. Portfolio which has stocks having market capitalization less than the median is named as 'small' while the other one having market capitalization more than the median is named as 'big'. Then both small and big portfolios are further divided. All stocks' book-to-market ratio is calculated and stocks of both big and small portfolios are then arranged in descending order. First $50 \%$ of stocks are then grouped as 'high' value stocks while the rest $50 \%$ are named as 'low' value stocks. This leads to the formation of further four portfolios namely SH, SL, BH and BL. Now to make quality based 
Table 5: Component matrix of quality

\begin{tabular}{lcc}
\hline \multicolumn{2}{c}{ Component } \\
\hline & 1 & 2 \\
\hline Profitability & 0.535 & 0.716 \\
Growth & 0.814 & \\
Safety & & \\
Payout & -0.561 & 0.691 \\
\hline
\end{tabular}

Note: No score for safety shows that safety cannot be considered as a component of quality. Thus it is not used in this study.

portfolio, composite index of quality is constructed and each stock's quality score is calculated. Now the stocks are arranged in ascending order and further divided in two groups named as 'quality' and 'junk'; quality, with high score and junk, with low score. This leads to the formation of further eight portfolios named as SHQ, SHJ, SLQ, SLJ, BHQ, BHJ, BLQ and BLJ.

$M K T=R_{m}-R F R$

$S M B=(S+S H+S L+S H Q+S H J+S L Q+S L J) \div 7(B+B H+B L+$ $B H Q+B H J+B L Q+B L J) \div 7$

$H M L=(S H+B H+S H Q+S H J+B H Q+B H J) \div 6(S L+B L+B L Q+$ $B L J+B L Q+B L J) \div 6$

$Q M J=(S H Q+S L Q+B H Q+B L Q) \div 4(S H J+S L J+B H J+B L J) \div 4$

\section{Results and discussion}

\subsection{Descriptive statistics}

Table 6 reports descriptive statistics of all portfolios constructed on the basis of market, size, value and quality. This table contains mean, maximum and minimum values of monthly returns and standard deviation of all of the portfolios for the study period (2008-2016). Results show the validity of CAPM i.e. higher returns are accompanied by higher level of risk and low returns with lower rate of risk.

Table 6 shows that portfolios comprising of small size quality stocks give higher returns than big size quality stocks. This result confirms the empirical findings of Asness et al (2018). Here SHQ has average return of $0.6812 \%$ at $12.8 \%$ risk while BHQ offers $0.3662 \%$ return at $10.2 \%$ level of risk. Similarly SLQ has average return of $-0.204 \%$ and standard deviation is $14.3 \%$ while average return of BLQ is $-0.262 \%$ and standard deviation is $20.5 \%$. Thus for our period of study SHQ and SLQ give higher returns than BHQ and BLQ respectively. As it can be clearly observed that small stocks yield higher returns than big stocks so these results are also consistent with the empirical work of (Banz 1981).

Lowest returns are offered by low $\mathrm{B} / \mathrm{M}$ ratio and junk stocks in both small

Business Review: (2020) 15(2):27-50 
SharBano et. al

Table 6: Descriptive statistics of all portfolios

\begin{tabular}{lccccccc}
\hline Portfolio & Mean & Median & Std Dev & Kurtosis & Skewness & Min & Max \\
\hline P & -0.0021 & 0.0004 & 0.1630 & 33.9306 & -0.8344 & -1.0884 & 0.7018 \\
S & -0.0039 & 0.0059 & 0.1283 & 18.5641 & -0.5881 & -0.7473 & 0.6715 \\
B & -0.0033 & 0.0079 & 0.1020 & 11.8918 & -0.0830 & -0.4295 & 0.5297 \\
SH & -0.0035 & 0.0035 & 0.1013 & 0.5714 & -0.0912 & -0.2975 & 0.2675 \\
SL & -0.0048 & -0.0038 & 0.1829 & 34.4112 & -0.8401 & -1.2274 & 0.1028 \\
BH & -0.0020 & 0.0074 & 0.0803 & 6.9617 & -1.5561 & -0.4206 & 0.1667 \\
BL & -0.0050 & -0.0035 & 0.1509 & 26.1211 & 1.5513 & -0.7122 & 0.9995 \\
SHQ & 0.0068 & 0.0081 & 0.1283 & 4.6841 & -0.3171 & -0.5324 & 0.5113 \\
SHJ & -0.0119 & -0.0111 & 0.1061 & 0.7997 & 0.1536 & -0.3140 & 0.3081 \\
SLQ & -0.0020 & 0.0001 & 0.1426 & 28.4391 & -1.7653 & -0.9635 & 0.7383 \\
SLJ & -0.0087 & -0.0070 & 0.2487 & 37.7155 & -0.1163 & -1.6418 & 0.6065 \\
BHQ & 0.0037 & 0.0129 & 0.1021 & 7.4447 & -1.6679 & -0.5248 & 0.2419 \\
BHJ & -0.0069 & -0.0031 & 0.0747 & 2.5794 & -0.5327 & -0.3101 & 0.2172 \\
BLQ & -0.0026 & -0.0018 & 0.2049 & 35.4667 & -1.6364 & -1.4245 & 0.1759 \\
BLJ & -0.0086 & -0.0054 & 0.1633 & 33.6202 & -0.7158 & -1.0884 & 0.6818 \\
\hline
\end{tabular}

size as well as big size companies. Average mean return of SLJ is $-0.873 \%$ and standard deviation is $24.8 \%$ while average mean return of BLJ is -0.856 and standard deviation is $16.3 \%$.

\subsection{Regression results}

To investigate the validity of market premium in the equity market of Pakistan, regression test is performed for all portfolios of the sample companies for the period of study (2008-2016).

\subsubsection{Regression results for market premium}

Results show that CAPM is valid in Pakistan's equity market because market premium is significantly positively related to all portfolios returns except SLJ which includes small size, low B/M ratio and junk quality stocks. Therefore market premium is priced in the equity market of Pakistan but this factor alone is not enough to explain the behavior of stock returns. Table 7 shows these results.

5.2.2 Regression results for market premium, size premium and value premium (Fama and French three factor model, 1992)

To check whether three factor model as proposed by Fama and French (1993) holds valid in equity market of Pakistan, regression test is run between these factors for the sample companies. Results indicate that inclusion of size and value premium in CAPM better explains the average returns as depicted through increased explanatory power of the three factor model presented by Fama and French (1992).

Size premium is significantly and positively related to all portfolios except 
Quality minus junk factor...

Table 7: Regression results for market premium $R_{t}=R F R+\beta_{1} M K T_{t}+\varepsilon_{t}$

\begin{tabular}{|c|c|c|c|c|c|}
\hline Dependent variable & Intercept & MKT & Adj. $R^{2}$ & F Stat & F sig \\
\hline $\mathrm{P}$ & -0.0037 & 0.6093 & 0.5609 & 60.8825 & 0.0637 \\
\hline T Statistic & -0.2319 & 2.7907 & & & \\
\hline $\mathrm{P}$ value & 0.8171 & 0.0064 & & & \\
\hline $\mathrm{S}$ & -0.0059 & 0.7076 & 0.5177 & 18.7893 & 0.0000 \\
\hline T Statistic & -0.4898 & 4.3347 & & & \\
\hline$P$ value & 0.6254 & 0.0000 & & & \\
\hline B & -0.0059 & 0.9414 & 0.4613 & 82.3360 & 0.0000 \\
\hline $\mathrm{T}$ Statistic & -0.7736 & 9.0739 & & & \\
\hline$P$ value & 0.4411 & 0.0000 & & & \\
\hline $\mathrm{SH}$ & -0.0061 & 0.9413 & 0.4673 & 84.3480 & 0.0000 \\
\hline T Statistic & -0.8040 & 9.1841 & & & \\
\hline $\mathrm{P}$ value & 0.4234 & 0.0000 & & & \\
\hline SL & -0.0062 & 0.5010 & 0.3009 & 40.2913 & 0.0476 \\
\hline T Statistic & -0.3361 & 2.0073 & & & \\
\hline $\mathrm{P}$ value & 0.7375 & 0.0476 & & & \\
\hline $\mathrm{BH}$ & -0.0047 & 0.9507 & 0.7646 & 309.6333 & 0.0000 \\
\hline $\mathrm{T}$ Statistic & -1.1717 & 17.5964 & & & \\
\hline$P$ value & 0.2443 & 0.0000 & & & \\
\hline BL & -0.0075 & 0.9179 & 0.3943 & 23.9134 & 0.0000 \\
\hline T Statistic & -0.5442 & 4.8901 & & & \\
\hline $\mathrm{P}$ value & 0.5876 & 0.0000 & & & \\
\hline SHQ & 0.0041 & 0.9934 & 0.3212 & 45.9622 & 0.0000 \\
\hline $\mathrm{T}$ Statistic & 0.3770 & 6.7795 & & & \\
\hline$P$ value & 0.7070 & 0.0000 & & & \\
\hline SHJ & -0.0144 & 0.9304 & 0.4154 & 68.5058 & 0.0000 \\
\hline $\mathrm{T}$ Statistic & -1.7434 & 8.2768 & & & \\
\hline $\mathrm{P}$ value & 0.0845 & 0.0000 & & & \\
\hline SLQ & -0.0033 & 0.4675 & 0.4889 & 69.8309 & 0.0172 \\
\hline T Statistic & -0.2342 & 2.4255 & & & \\
\hline $\mathrm{P}$ value & 0.8154 & 0.0172 & & & \\
\hline SLJ & -0.0100 & 0.4713 & 0.4824 & 68.8645 & 0.1729 \\
\hline $\mathrm{T}$ Statistic & -0.3967 & 1.3735 & & & \\
\hline$P$ value & 0.6925 & 0.1729 & & & \\
\hline BHQ & 0.0008 & 1.0484 & 0.5734 & 128.6762 & 0.0000 \\
\hline $\mathrm{T}$ Statistic & 0.1129 & 11.3436 & & & \\
\hline$P$ value & 0.9103 & 0.0000 & & & \\
\hline BHJ & -0.0092 & 0.8298 & 0.6723 & 195.8680 & 0.0000 \\
\hline T Statistic & -2.1072 & 13.9953 & & & \\
\hline $\mathrm{P}$ value & 0.0378 & 0.0000 & & & \\
\hline BLQ & -0.0062 & 1.2828 & 0.2064 & 25.7131 & 0.0000 \\
\hline $\mathrm{T}$ Statistic & -0.3303 & 5.0708 & & & \\
\hline$P$ value & 0.7419 & 0.0000 & & & \\
\hline BLJ & -0.0101 & 0.5560 & 0.5360 & 63.7999 & 0.0000 \\
\hline $\mathrm{T}$ Statistic & -0.6220 & 2.5259 & & & \\
\hline$P$ value & 0.5354 & 0.0132 & & & \\
\hline
\end{tabular}

Note: Here $\mathrm{P}$ is portfolio including all sample companies, $\mathrm{S}$ is portfolio including only small size companies, $\mathrm{B}$ is portfolio having all big size companies, $\mathrm{SH}$ is portfolio including small size and high $\mathrm{B} / \mathrm{M}$ ratio firms, SL portfolio has small size and low $\mathrm{B} / \mathrm{M}$ ratio firms, $\mathrm{BH}$ is portfolio having big size and high $\mathrm{B} / \mathrm{M}$ ratio firms, BL portfolio includes big size and low B/M ratio firms, SHQ portfolio includes small size, high $\mathrm{B} / \mathrm{M}$ ratio firms with high quality stocks, SHJ portfolio includes small size, high $\mathrm{B} / \mathrm{M}$ ratio firms with junk stocks, SLQ is portfolio having small size, low B/M ratio and quality stocks, SLJ includes small size, low $\mathrm{B} / \mathrm{M}$ ratio firms with junk stocks, $\mathrm{BHQ}$ is portfolio having big size firms with high $\mathrm{B} / \mathrm{M}$ ratio and junk stocks, $\mathrm{BHJ}$ portfolio includes big size, high $\mathrm{B} / \mathrm{M}$ ratio firms with junk stocks, BLQ is portfolio having big size, low $\mathrm{B} / \mathrm{M}$ ratio and quality stocks, BLJ includes big size, low B/M ratio firms with junk stocks.

Business Review: (2020) 15(2):27-50 
$\mathrm{BH}, \mathrm{BHQ}$ and $\mathrm{BLQ}$ where it is insignificant and negatively related to the average portfolio returns. It is also insignificant in case of BHJ where it is related to portfolio returns positively. Thus size premium better explains average returns of small stocks as compared to big stocks. This finding is consistent with the empirical research of Hassan and Javed (2011) who studied the effect of size and value premium in the equity market of Pakistan.

Value premium also shows inconsistent behavior. It is significant yet negatively related to all portfolio returns except in case of BH, BHQ, BLQ and $\mathrm{BHJ}$ where it is found insignificant and positively related to $\mathrm{BH}$ and BHJ. It shows that value premium better explains returns of stocks with low book-tomarket ratio and it is not completely redundant as suggested by Fama and French (2015). These results confirm the empirical findings of Fama and French (1993) and Lin (2017). Therefore B/M factor is also a priced factor in the equity market of Pakistan. Results are shown in table 8.

\subsubsection{Regression results of the proposed four-factor model}

To explore the relationship between portfolio returns and market premium, size premium, value premium and quality minus junk factor, regression analysis was performed and its results are presented in the table 9. According to the empirical findings, market premium is found to be positive and significant for all types of portfolios which is in line with the capital asset pricing model (Sharpe, 1964). This means that this factor effects stock returns and must always be considered while making any economic decision.

The size premium shows a mixed behavior. It is significant and positively related to all portfolios except BH, BHQ, BHJ, BLQ. This means that SMB does not influence returns of big stocks. This result is consistent with the findings of Hassan and Javed (2011) who studied the effect of size and value premium in the equity market of Pakistan.

Value premium also does not show consistent behavior. It is significantly negatively related to all portfolios except $\mathrm{BH}, \mathrm{BHQ}, \mathrm{BHJ}, \mathrm{BLQ}$ where it is found insignificant. Thus value premium is priced in case of small size companies. $\mathrm{T}$-stat values also show that $\mathrm{B} / \mathrm{M}$ ratio better explains returns of portfolios comprising of low $\mathrm{B} / \mathrm{M}$ ratio stocks than portfolios constructed on the basis of high $\mathrm{B} / \mathrm{M}$ ratio.

According to the results, QMJ (quality minus junk factor) is found to be significant and positively related to SHQ and BHQ returns and significantly but negatively related to SHJ, SLJ and BHJ by analyzing t-stat values. This means that quality stocks have high risk adjusted returns while junk stocks yield low or negative risk adjusted returns. Negative returns might also be because of the negative impact of unstable political conditions in Pakistan during the study period (2008-2016) when the stock market became stagnant for some period. Here also small size quality stocks outperform the big size quality stocks where SHQ offers $0.6812 \%$ return while average return of BHQ is $0.3662 \%$. Similarly average return of SLQ is -0.204 while average return of BLQ is -0.262 . In case of junk stocks big size junk stocks give higher returns than small size junk stocks; average return of BHJ is $-0.692 \%$ while SHJ average return is $-1.187 \%$. Thus 
Quality minus junk factor...

Table 8: Regression results for market premium, size premium and value premium $R_{t}=$ $R F R+\beta_{1} M K T_{t}+\beta_{2} S M B_{t}+\beta_{3} H M L+\varepsilon_{t}$

\begin{tabular}{|c|c|c|c|c|c|c|c|}
\hline Dependent variable & Intercept & MKT & SMB & HML & Adj. $R^{2}$ & F Stat & F sig. \\
\hline $\mathrm{P}$ & -0.012 & 0.888 & 1.147 & -0.676 & 0.642 & 57.749 & 0.000 \\
\hline T Statistic & -1.172 & 6.350 & 6.834 & -7.362 & & & \\
\hline $\mathrm{P}$ value & 0.244 & 0.000 & 0.000 & 0.000 & & & \\
\hline $\mathrm{S}$ & -0.011 & 0.967 & 1.111 & -0.641 & 0.731 & 87.262 & 0.000 \\
\hline $\mathrm{T}$ Statistic & -1.583 & 10.149 & 9.712 & -10.241 & & & \\
\hline $\mathrm{P}$ value & 0.117 & 0.000 & 0.000 & 0.000 & & & \\
\hline B & -0.011 & 1.011 & 0.233 & -0.154 & 0.786 & 117.429 & 0.000 \\
\hline T Statistic & -2.282 & 14.953 & 2.874 & -3.478 & & & \\
\hline $\mathrm{P}$ value & 0.025 & 0.000 & 0.005 & 0.001 & & & \\
\hline SH & -0.007 & 1.080 & 0.624 & -0.351 & 0.634 & 55.897 & 0.000 \\
\hline T Statistic & -1.086 & 12.297 & 5.924 & -6.079 & & & \\
\hline $\mathrm{P}$ value & 0.280 & 0.000 & 0.000 & 0.000 & & & \\
\hline SL & -0.015 & 0.865 & 1.529 & -0.891 & 0.684 & 69.472 & 0.000 \\
\hline $\mathrm{T}$ Statistic & -1.398 & 5.867 & 8.640 & -9.202 & & & \\
\hline $\mathrm{P}$ value & 0.165 & 0.000 & 0.000 & 0.000 & & & \\
\hline $\mathrm{BH}$ & -0.006 & 0.951 & -0.018 & 0.005 & 0.777 & 111.651 & 0.000 \\
\hline T Statistic & -1.475 & 17.500 & -0.276 & 0.135 & & & \\
\hline $\mathrm{P}$ value & 0.144 & 0.000 & 0.783 & 0.893 & & & \\
\hline BL & -0.017 & 1.063 & 0.509 & -0.329 & 0.727 & 85.236 & 0.000 \\
\hline T Statistic & -2.100 & 9.403 & 3.750 & -4.426 & & & \\
\hline $\mathrm{P}$ value & 0.038 & 0.000 & 0.000 & 0.000 & & & \\
\hline SHQ & 0.000 & 1.174 & 0.766 & -0.444 & 0.614 & 51.452 & 0.000 \\
\hline T Statistic & 0.034 & 10.280 & 5.593 & -5.923 & & & \\
\hline$P$ value & 0.973 & 0.000 & 0.000 & 0.000 & & & \\
\hline SHJ & -0.012 & 1.018 & 0.434 & -0.232 & 0.476 & 29.809 & 0.000 \\
\hline $\mathrm{T}$ Statistic & -1.585 & 9.254 & 3.291 & -3.211 & & & \\
\hline $\mathrm{P}$ value & 0.116 & 0.000 & 0.001 & 0.002 & & & \\
\hline SLQ & -0.009 & 0.768 & 1.293 & -0.744 & 0.640 & 57.246 & 0.000 \\
\hline T Statistic & -0.977 & 6.263 & 8.787 & -9.238 & & & \\
\hline $\mathrm{P}$ value & 0.331 & 0.000 & 0.000 & 0.000 & & & \\
\hline SLJ & -0.023 & 0.928 & 1.879 & -1.108 & 0.675 & 66.715 & 0.000 \\
\hline $\mathrm{T}$ Statistic & -1.590 & 4.565 & 7.704 & -8.299 & & & \\
\hline$P$ value & 0.115 & 0.000 & 0.000 & 0.000 & & & \\
\hline BHQ & -0.002 & 1.054 & -0.018 & -0.002 & 0.629 & 54.778 & 0.000 \\
\hline T Statistic & -0.281 & 11.828 & -0.171 & -0.038 & & & \\
\hline $\mathrm{P}$ value & 0.779 & 0.000 & 0.864 & 0.969 & & & \\
\hline BHJ & -0.009 & 0.824 & -0.025 & 0.014 & 0.666 & 64.170 & 0.000 \\
\hline T Statistic & -2.048 & 13.315 & -0.331 & 0.351 & & & \\
\hline $\mathrm{P}$ value & 0.043 & 0.000 & 0.742 & 0.727 & & & \\
\hline BLQ & -0.018 & 1.340 & 0.061 & -0.093 & 0.568 & 42.705 & 0.000 \\
\hline $\mathrm{T}$ Statistic & -1.323 & 6.945 & 0.265 & -0.732 & & & \\
\hline $\mathrm{P}$ value & 0.189 & 0.000 & 0.792 & 0.466 & & & \\
\hline BLJ & -0.018 & 0.816 & 1.054 & -0.626 & 0.607 & 49.835 & 0.000 \\
\hline $\mathrm{T}$ Statistic & -1.748 & 5.557 & 5.985 & -6.493 & & & \\
\hline $\mathrm{P}$ value & 0.084 & 0.000 & 0.000 & 0.000 & & & \\
\hline
\end{tabular}

Note: Here $\mathrm{P}$ is portfolio including all sample companies, $\mathrm{S}$ is portfolio including only small size companies, $\mathrm{B}$ is portfolio having all big size companies, $\mathrm{SH}$ is portfolio including small size and high $\mathrm{B} / \mathrm{M}$ ratio firms, SL portfolio has small size and low $\mathrm{B} / \mathrm{M}$ ratio firms, $\mathrm{BH}$ is portfolio having big size and high $\mathrm{B} / \mathrm{M}$ ratio firms, $\mathrm{BL}$ portfolio includes big size and low $\mathrm{B} / \mathrm{M}$ ratio firms, SHQ portfolio includes small size, high B/M ratio firms with high quality stocks, SHJ portfolio includes small size, high $\mathrm{B} / \mathrm{M}$ ratio firms with junk stocks, SLQ is portfolio having small size, low B/M ratio and quality stocks, SLJ includes small size, low B/M ratio firms with junk stocks, BHQ is portfolio having big size firms with high $\mathrm{B} / \mathrm{M}$ ratio and junk stocks, BHJ portfolio includes big size, high B/M ratio firms with junk stocks, BLQ is portfolio having big size, low $\mathrm{B} / \mathrm{M}$ ratio and quality stocks, BLJ includes big size, low B/M ratio firms with junk stocks.

Business Review: (2020) 15(2):27-50 
SharBano et. al

Table 9: Regression results of proposed four-factor model: $R_{t}=R F R+\beta_{1} M K T_{t}+\beta_{2} S M B_{t}+$ $\beta_{3} H M L+\beta_{4} Q M J_{t}+\varepsilon_{t}$

\begin{tabular}{|c|c|c|c|c|c|c|c|c|}
\hline $\mathrm{D}$ variable & intercept & MKT & SMB & HML & QMJ & Adj. $R^{2}$ & F Stat & F sig. \\
\hline $\mathrm{P}$ & -0.0114 & 0.8944 & 1.1404 & -0.6803 & -0.0344 & 0.6380 & 42.8576 & 0.0000 \\
\hline T Statistic & -1.0920 & 6.0938 & 6.5494 & -7.0609 & -0.1525 & & & \\
\hline$P$ value & 0.2777 & 0.0000 & 0.0000 & 0.0000 & 0.8791 & & & \\
\hline $\mathrm{S}$ & -0.0112 & 0.9607 & 1.1174 & -0.6366 & 0.0352 & 0.7287 & 64.7854 & 0.0000 \\
\hline T Statistic & -1.5821 & 9.6058 & 9.4185 & -9.6981 & 0.2287 & & & \\
\hline $\mathrm{P}$ value & 0.1171 & 0.0000 & 0.0000 & 0.0000 & 0.8196 & & & \\
\hline B & -0.0119 & 0.9966 & 0.2474 & -0.1452 & 0.0752 & 0.7850 & 87.6910 & 0.0000 \\
\hline $\mathrm{T}$ Statistic & -2.3758 & 14.0847 & 2.9476 & -3.1265 & 0.6909 & & & \\
\hline $\mathrm{P}$ value & 0.0196 & 0.0000 & 0.0041 & 0.0024 & 0.4914 & & & \\
\hline $\mathrm{SH}$ & -0.0074 & 1.0711 & 0.6335 & -0.3447 & 0.0480 & 0.6306 & 41.5481 & 0.0000 \\
\hline T Statistic & -1.1309 & 11.6257 & 5.7963 & -5.7007 & 0.3385 & & & \\
\hline$P$ value & 0.2611 & 0.0000 & 0.0000 & 0.0000 & 0.7358 & & & \\
\hline SL & -0.0149 & 0.8627 & 1.5309 & -0.8894 & 0.0123 & 0.6803 & 51.5397 & 0.0000 \\
\hline $\mathrm{T}$ Statistic & -1.3601 & 5.5745 & 8.3391 & -8.7557 & 0.0514 & & & \\
\hline$P$ value & 0.1772 & 0.0000 & 0.0000 & 0.0000 & 0.9591 & & & \\
\hline $\mathrm{BH}$ & -0.0070 & 0.9292 & 0.0039 & 0.0188 & 0.0048 & 0.7793 & 84.8648 & 0.0000 \\
\hline T Statistic & -1.7622 & 16.4516 & 0.0587 & 0.5081 & 0.1347 & & & \\
\hline$P$ value & 0.0814 & 0.0000 & 0.9533 & 0.6126 & 0.8932 & & & \\
\hline BL & -0.0175 & 1.0549 & 0.5168 & -0.3233 & 0.0426 & 0.7239 & 63.2834 & 0.0000 \\
\hline $\mathrm{T}$ Statistic & -2.0820 & 8.8936 & 3.6727 & -4.1529 & 0.2336 & & & \\
\hline $\mathrm{P}$ value & 0.0402 & 0.0000 & 0.0004 & 0.0001 & 0.8158 & & & \\
\hline SHQ & -0.0041 & 1.1030 & 0.8390 & -0.3978 & 0.3807 & 0.6284 & 41.1599 & 0.0000 \\
\hline T Statistic & -0.4889 & 9.4241 & 6.0428 & -5.1786 & 2.1135 & & & \\
\hline$P$ value & 0.6261 & 0.0000 & 0.0000 & 0.0000 & 0.0373 & & & \\
\hline SHJ & -0.0096 & 1.0649 & 0.3867 & -0.2625 & -0.2320 & 0.4822 & 23.1190 & 0.0000 \\
\hline $\mathrm{T}$ Statistic & -1.1914 & 9.3243 & 2.8540 & -3.5023 & -3.2109 & & & \\
\hline $\mathrm{P}$ value & 0.2366 & 0.0000 & 0.0053 & 0.0007 & 0.0018 & & & \\
\hline SLQ & -0.0115 & 0.7205 & 1.3420 & -0.7129 & 0.2556 & 0.6425 & 43.6831 & 0.0000 \\
\hline T Statistic & -1.2720 & 5.6484 & 8.8683 & -8.5141 & 1.3021 & & & \\
\hline$P$ value & 0.2066 & 0.0000 & 0.0000 & 0.0000 & 0.1962 & & & \\
\hline SLJ & -0.0207 & 0.9688 & 1.8378 & -1.1344 & -1.1078 & 0.6728 & 49.8443 & 0.0000 \\
\hline $\mathrm{T}$ Statistic & -1.3716 & 4.5512 & 7.2782 & -8.1193 & -8.2990 & & & \\
\hline$P$ value & 0.1736 & 0.0000 & 0.0000 & 0.0000 & 0.0000 & & & \\
\hline $\mathrm{BHQ}$ & -0.0076 & 0.9579 & 0.0795 & 0.0603 & 0.5133 & 0.6777 & 50.9403 & 0.0000 \\
\hline $\mathrm{T}$ Statistic & -1.2432 & 11.0459 & 0.7727 & 1.0592 & 3.8460 & & & \\
\hline$P$ value & 0.2170 & 0.0000 & 0.4417 & 0.2923 & 0.0002 & & & \\
\hline BHJ & -0.0057 & 0.8798 & -0.0816 & -0.0222 & -0.2994 & 0.6957 & 55.2959 & 0.0000 \\
\hline T Statistic & -1.2990 & 14.2656 & -1.1152 & -0.5491 & -3.1541 & & & \\
\hline $\mathrm{P}$ value & 0.1972 & 0.0000 & 0.2677 & 0.5843 & 0.0022 & & & \\
\hline BLQ & -0.0231 & 1.2614 & 0.1413 & -0.0415 & 0.4202 & 0.5724 & 32.7900 & 0.0000 \\
\hline $\mathrm{T}$ Statistic & -1.6243 & 6.2921 & 0.5942 & -0.3157 & 1.3619 & & & \\
\hline$P$ value & 0.1078 & 0.0000 & 0.5539 & 0.7529 & 0.1766 & & & \\
\hline BLJ & -0.0145 & 0.8784 & 0.9898 & -0.6668 & -0.3369 & 0.6111 & 38.3253 & 0.0000 \\
\hline T Statistic & -1.3478 & 5.7663 & 5.4777 & -6.6691 & -1.4372 & & & \\
\hline$P$ value & 0.1811 & 0.0000 & 0.0000 & 0.0000 & 0.1541 & & & \\
\hline
\end{tabular}

Note: Here $\mathrm{P}$ is portfolio including all sample companies, $\mathrm{S}$ is portfolio including only small size companies, B is portfolio having all big size companies, $\mathrm{SH}$ is portfolio including small size and high $\mathrm{B} / \mathrm{M}$ ratio firms, SL portfolio has small size and low $\mathrm{B} / \mathrm{M}$ ratio firms, $\mathrm{BH}$ is portfolio having big size and high $\mathrm{B} / \mathrm{M}$ ratio firms, BL portfolio includes big size and low B/M ratio firms, SHQ portfolio includes small size, high B/M ratio firms with high quality stocks, SHJ portfolio includes small size, high $\mathrm{B} / \mathrm{M}$ ratio firms with junk stocks, SLQ is portfolio having small size, low $\mathrm{B} / \mathrm{M}$ ratio and quality stocks, SLJ includes small size, low B/M ratio firms with junk stocks, BHQ is portfolio having big size firms with high $\mathrm{B} / \mathrm{M}$ ratio and junk stocks, BHJ portfolio includes big size, high $\mathrm{B} / \mathrm{M}$ ratio firms with junk stocks, BLQ is portfolio having big size, low B/M ratio and quality stocks, BLJ includes big size, low $\mathrm{B} / \mathrm{M}$ ratio firms with junk stocks. 
quality of stocks is a priced factor in the equity market of Pakistan and therefore this study confirms the empirical findings of Asness et al (2018) who suggested that quality of stocks must be considered as a risk factor while analyzing future expected stock returns. Therefore, returns calculated using this proposed 4factor model having QMJ as a risk factor can be compared to market returns by investors, as market returns provide a benchmark and investors can not only judge the overall market condition but can also compare their own performance with the market performance through this comparison.

\subsubsection{Comparison of explanatory power of CAPM, Fama and French three-factor model and proposed four-factor model through adjusted $R^{2}$}

To examine the explanatory power of CAPM, three factor model (Fama and French, 1992) and proposed four factor model, adjusted $R^{2}$ values are compared. As it can be clearly observed that although market premium is priced in all portfolio returns yet this single factor does not have the ability to fully explain the portfolio returns. Addition of size and value premium in single factor model increases its explanatory power to many folds in case of all portfolios. Thus three factor model performs better than CAPM.

As far as addition of quality minus junk factor in three factor model is concerned, it also brought an increase in the explanatory power of subsequent portfolio returns but this increase in not very significant. This increase in explanatory power is observed in case of BH, SHQ, SHJ, SLQ, BHQ, BHJ, BLQ and BLJ portfolios. Among these portfolios, highest increase in explanatory power is noticed in case of $\mathrm{BHQ}$ portfolio where adjusted $R^{2}$ value of three factor model is 0.6294 and that of the proposed four factor model is 0.6777 . Hence the difference in adjusted $R^{2}$ values of the three factor model and the proposed four factor model is $4.83 \%$. Results are displayed in table 10 .

Moreover, as it is difficult to incorporate all the variables which may affect an asset's price, completely in one single model (Fama and French 1993), the negative insignificant values of intercept of CAPM and three factor model in our proposed model show that there might be some idiosyncratic risk or other omitted variables which could not have been incorporated in this model.

\section{Conclusions and recommendations}

\subsection{Conclusion}

The literature in asset pricing is not yet able to explain fully the variation in cross sectional returns of the stocks. Therefore, there is a need to explore more risk factors which influence and can better explain variation in the stock returns. Asness et al (2018) constructed a quality minus junk factor which when tested, came out to be a priced factor in describing the behavior of stock returns in developed markets. According to Zaremba (2015) this quality minus junk factor (QMJ) may have country specific properties, hence there is a need to check its validity in other countries as well.

Business Review: (2020) 15(2):27-50 
Table 10: Comparison of adjusted $R^{2}$ values of single factor, 3 factor and proposed 4 factor model

\begin{tabular}{lccc}
\hline Portfolios & MKT & $3 \mathrm{~F}$ & PM \\
\hline P & 0.5609 & 0.6418 & 0.6380 \\
S & 0.5177 & 0.7315 & 0.7287 \\
B & 0.4613 & 0.7862 & 0.7850 \\
SH & 0.4673 & 0.6342 & 0.6306 \\
SL & 0.3090 & 0.6838 & 0.6803 \\
BH & 0.7646 & 0.7775 & 0.7793 \\
BL & 0.3943 & 0.7268 & 0.7239 \\
SHQ & 0.3212 & 0.6144 & 0.6284 \\
SHJ & 0.4154 & 0.4764 & 0.4822 \\
SLQ & 0.4889 & 0.6398 & 0.6425 \\
SLJ & 0.4824 & 0.6748 & 0.6728 \\
BHQ & 0.5734 & 0.6294 & 0.6777 \\
BHJ & 0.6723 & 0.6661 & 0.6957 \\
BLQ & 0.2064 & 0.5684 & 0.5724 \\
BLJ & 0.5316 & 0.6066 & 0.6111 \\
\hline
\end{tabular}

Note: Here $\mathrm{P}$ is portfolio including all sample companies, $\mathrm{S}$ is portfolio including only small size companies, $\mathrm{B}$ is portfolio having all big size companies, $\mathrm{SH}$ is portfolio including small size and high $\mathrm{B} / \mathrm{M}$ ratio firms, SL portfolio has small size and low $\mathrm{B} / \mathrm{M}$ ratio firms, $\mathrm{BH}$ is portfolio having big size and high $\mathrm{B} / \mathrm{M}$ ratio firms, BL portfolio includes big size and low $\mathrm{B} / \mathrm{M}$ ratio firms, SHQ portfolio includes small size, high $\mathrm{B} / \mathrm{M}$ ratio firms with high quality stocks, SHJ portfolio includes small size, high $\mathrm{B} / \mathrm{M}$ ratio firms with junk stocks, SLQ is portfolio having small size, low $\mathrm{B} / \mathrm{M}$ ratio and quality stocks, SLJ includes small size, low B/M ratio firms with junk stocks, BHQ is portfolio having big size firms with high $\mathrm{B} / \mathrm{M}$ ratio and junk stocks, BHJ portfolio includes big size, high $\mathrm{B} / \mathrm{M}$ ratio firms with junk stocks, BLQ is portfolio having big size, low $\mathrm{B} / \mathrm{M}$ ratio and quality stocks, $\mathrm{BLJ}$ includes big size, low B/M ratio firms with junk stocks.

According to the best of our knowledge this specific study is the first one to empirically test the validity of QMJ factor in the equity market of Pakistan which is an emerging market of Asia. Results of this study are very interesting. First of all, as suggested by Asness et al (2018), quality has four components; profitability, growth, safety and payout, when these components were tested through principal component analysis safety came out to be a redundant measure of quality therefore it was excluded during the composition of the quality factor. Thus in this study profitability, growth and payout have been used collectively for analyzing the impact of the quality factor on portfolio returns. After testing QMJ factor along with the market, size and value, results show 
that quality is a risk factor in the equity market of Pakistan. Quality stocks outperform junk stocks (Asness et al 2018). But inclusion of QMJ factor in the three-factor model of Fama and French (1993) does not enhance the explanatory power of the proposed four factor model significantly. Highest increase in explanatory power of proposed four factor is observed in case of BHQ portfolio where difference in explanatory power, captured through adjusted $R^{2}$ values, of Fama and French (1993) and proposed four factor model is $4.83 \%$.

The findings of this study also confirm some other recent research work. For example, Asness et al (2018), showed that small size quality stocks outperform big size quality stocks. Similar results are captured in this study as well. Lin (2017) suggests that value premium is not a redundant factor completely in contrast to Fama and French (2015). This empirical study also approves findings of Lin (2017) suggesting that along with market, size and quality factors, value premium is not a redundant factor and must be considered while predicting portfolio returns.

\subsection{Implications of the study}

This particular research does not only contribute to literature but it also provides an insight to market investors, corporate managers and government authorities to better understand the relationship between stock returns and various risk factors prevailing in the whole economy.

This study draws attention of market investors towards quality of stocks which they must keep in mind while investing in different kinds of stocks. By foreseeing any changes in quality measures of stocks they can bring change in their investment pattern and avoid losses. Managers must also make strategies that positively contribute to the profitability and growth of the company that will ultimately make the quality of their stocks better. A stable payout to the investors must also be a manager's responsibility because payout ratio also affects the stocks' quality.

On the other hand, as Pakistan is an emerging market of Asia and due to prominent changes in its political as well as economic environment, it has gained much more investors attention than before. Therefore to attract more foreign investment and increased economic growth government should also take certain measures to improve the equity market performance. One of the several ways to do so is to help companies by reducing their tax burden which ultimately may increase their profitability and growth and may have positive effect on investors returns as well.

\subsection{Limitations of the study}

Although this study has several empirical contributions and it practically also provides better understanding of returns and various risks relationship to the stakeholders yet it has certain limitations as well which are discussed below.

- First of all this study is conducted in the equity market of Pakistan. As asset pricing factors are country specific (Griffin 2002), there is a chance that this

Business Review: (2020) 15(2):27-50 
new proposed risk factor of QMJ will behave differently in other markets. Its behavior with regard to other markets has not been explored in this specific study.

- This study has a limited sample size and time period. Here 70 non-financial companies are included from the equity market of Pakistan for the period of 2008-2016.

\subsection{Directions for future research}

The findings of this specific study lead researchers to explore new risk factors in asset pricing and test already explored factors to check their validity in different markets.

- Firstly, QMJ factor has four components; profitability, growth, safety and payout. Our findings suggest that in the composition of quality, safety is a redundant measure but its reasons for being redundant have not been explored here.

- Secondly, as stated by Zaremba (2015) QMJ has country specific properties so this factor must be tested in other countries as well to check its overall validity.

- Thirdly, although QMJ is a risk factor but its addition in Fama and French three-factor model does not increase explanatory power of the model significantly. This might be due to the weak composition of the quality index. Therefore there is a need to explore other measures that can help in developing a better quality composite index that has the power to better explain stock returns behavior.

\section{References}

Acharya VV, Pedersen LH (2005) Asset pricing with liquidity risk. Journal of financial Economics $77(2): 375-410$

Ang A, Hodrick RJ, Xing Y, Zhang X (2006) The cross-section of volatility and expected returns. The Journal of Finance 61(1):259-299

Asness C, Frazzini A, Israel R, Moskowitz TJ, Pedersen LH (2018) Size matters, if you control your junk. Journal of Financial Economics 129(3):479-509

Banz RW (1981) The relationship between return and market value of common stocks. Journal of financial economics $9(1): 3-18$

Black F (1976) The dividend puzzle, the harder we look at the dividend picture, the more it seems like a puzzle, with pieces that just dont fit together,. The Journal of Portfolio Management 2(2)

Dichev ID (1998) Is the risk of bankruptcy a systematic risk? the Journal of Finance $53(3): 1131-1147$

Fama EF, French KR (1993) Common risk factors in the returns on stocks and bonds. Journal of

Fama EF, French KR (1998) Value versus growth: The international evidence. The journal of finance 53(6):1975-1999

Fama EF, French KR (2015) A five-factor asset pricing model. Journal of financial economics 116(1):1-22

Frankel R, Lee CM (1998) Accounting valuation, market expectation, and cross-sectional stock returns. Journal of Accounting and economics 25(3):283-319 
Fu F (2009) Idiosyncratic risk and the cross-section of expected stock returns. Journal of financial Economics 91(1):24-37

George TJ, Hwang CY (2010) A resolution of the distress risk and leverage puzzles in the cross section of stock returns. Journal of Financial Economics 96(1):56-79

Griffin JM (2002) Are the fama and french factors global or country specific? The Review of Financial Studies 15(3):783-803

Hassan A, Javed MT (2011) Size and value premium in pakistani equity market. African Journal of Business Management 5(16):6747-6755

Hussainey K, Mgbame CO, Chijoke-Mgbame AM (2011) Dividend policy and share price volatility: Uk evidence. The Journal of risk finance

Lin Q (2017) Noisy prices and the fama-french five-factor asset pricing model in china. Emerging Markets Review 31:141-163

Novy-Marx R (2013) The other side of value: The gross profitability premium. Journal of Financial Economics 108(1):1-28

Pontiff J, Woodgate A (2008) Share issuance and cross-sectional returns. The Journal of Finance 63(2):921-945

Zaremba A (2015) Country selection strategies based on quality. Managerial Finance

\section{Appendix}

Definition of variables

In this section details of all components of quality used in this study are discussed. Definitions of quality components are based on the previous work presented by Asness et al (2018).

\section{Profitability}

Profitability is calculated by averaging z-scores of gross profit over assets, return on equity, return on assets, cash flow over assets, gross margin and low accruals.

Profitability $=z\left(z_{\text {gpoa }}+z_{\text {roe }}+z_{\text {roa }}+z_{c f o a}+z_{\text {gmar }}+z_{\text {acc }}\right)$

These proxies are discussed below:

Gross profit over assets (GPOA): It is equal to revenue minus cost of goods sold divided by total assets.

GPOA $=($ Revenue - cost of goods sold $) /($ Total assets $)$

Return on equity: It is net income divided by book-equity.

$R O E=($ Net income $) /($ Book equity $)$

Here, book equity (BE) is defined as "Shareholders' equity minus preferred stock".

Return on assets: It is net income divided by total assets.

$R O A=($ Net income $) /($ Total assets $)$

Business Review: (2020) 15(2):27-50 
Cash flow over assets: CFOA is net income plus depreciation minus changes in working capital and capital expenditures divided by total assets.

CFOA $=\frac{(\text { Net income }+ \text { Depreciation }-\Delta \text { in working capital }+ \text { Capital expenditures })}{(\text { Total assets })}$

Here, Working capital (WC) is defined as "current assets minus current liabilities minus cash and short term instruments plus short term debt and income taxes payable"

Gross Margin: It is the revenue minus cost of goods sold divided by total sales.

GMAR $=($ Revenue - Cost of goods sold $) /$ Sales

Low accruals: Low accruals (ACC) is depreciation minus changes in working capital.

$A C C=(-(\Delta$ in working capital - depreciation $)) /($ Total assets $)$

Growth

Growth measure is calculated by averaging z-scores of one year growth in gross profits over assets, return on equity, return on assets, cash flow over assets, gross margin and low accruals.

Growth $=z\left(z_{\Delta g p o a}+z_{\Delta r o e}+z_{\Delta r o a}+z_{\Delta c f o a}+z_{\Delta g m a r}+z_{\Delta a c c}\right)$

Growth in gross profits over assets:

It is calculated as follows

$=\left(\right.$ Gross profit $_{t}-$ Gross profit $\left._{t-5}\right) /\left(\right.$ total $_{\text {asset }}$ pr-5 $)$

Growth in return on equity:

It is five year growth in net income over assets computed as

$=\left(\right.$ Net income $_{t}-$ Net income $\left._{t-5}\right) /\left(\right.$ Book equity $\left._{t-5}\right)$

Growth in return on assets:

For calculating growth in returns on assets, growth of net income over the period of five years is divided by total assets.

$=\left(\right.$ net $_{\text {income }_{t}}-$ net income $\left._{t-5}\right) /\left(\right.$ total $\left._{\text {asset }}{ }_{t-5}\right)$

Growth in cash flows over assets: 
Growth in cash flows over assets over the period of five years is calculated as:

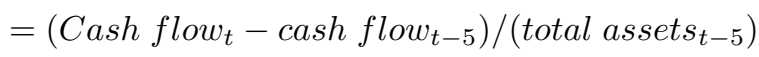

Growth in gross margin:

It is computed as:

$=\left({\left.\text { Gross } \text { margin }_{t}-\text { Gross } \text { margin }_{t-5}\right) /\left(\text { sales }_{t-5}\right)}\right.$

Growth in low accruals (ACC):

Five year growth in (low) accruals is determined as follows:

$=\left(A C C_{t}-A C C_{t-5}\right) /\left(\right.$ total $\left._{\text {assets }}+5\right)$

Safety

This measure of safety is calculated by averaging z-scores of low beta, low idiosyncratic volatility, low leverage, low bankruptcy risk and low earnings volatility.

Safety $=z\left(z_{\text {bab }}+z_{\text {ivol }}+z_{\text {lev }}+z_{z}+z_{\text {evol }}\right)$

Here, Low Beta (BAB) is equal to negative market beta i.e. $\beta$. Low idiosyncratic volatility (IVOL) is determined by calculating rolling one-year standard deviation of daily beta-adjusted excess returns, neglecting the most recent trading day. Low leverage(LEV) is calculated by dividing total debt with total assets. Total debt includes long term as well as short term debt, minority interest and preferred stock.

Altman's z-score will be used to calculate the bankruptcy risk, where Z-score is equal to weighted average of working capital, retained earnings, earnings before interest and taxes, market equity and sales divided by total assets.

$Z-$ score $=(1.2 W C+1.4 R E+3.3 E B I T+0.6 M E+$ Sales $) /$ Total assets

Payout

Payout z-score is computed by averaging z-scores of net equity issuance(EISS), net debt issuance and total net payout over profits (NPOP).

Payout $=z\left(z_{\text {eiss }}+z_{\text {diss }}+z_{\text {npop }}\right)$

Here,

Net equity issuance(EISS): EISS is equal to minus one-year percent change

Business Review: (2020) 15(2):27-50 
change in split-adjusted number of shares.

$E I S S=-\log \left(S H R O U T_{-} A D J_{t} / S H R O U T_{-} A D J_{t-1}\right)$

Here, SHROUT_ADJ is split adjusted shares outstanding.

Net debt issuance(DISS):It is computed as minus one year percent change in total debt.

$D I S S=-\log \left(T O T D_{t} / T O T D_{t-1}\right)$

Net payout over profits(NPOP):NPOP is calculated by subtracting changes in book equity over past five years from net income and dividing it by total profits over past five years.

$N P O P=$ Net income $-\Delta$ Book equity/Total profits 